\title{
Prevalensi Servisitis Gonore pada Wanita Hamil di Rumah Sakit Khusus Ibu dan Anak Kota Bandung Tahun 2015
}

\author{
Armina Haramaini, Rachmatdinata, Rasmia Rowawi \\ Departemen Ilmu Kesehatan Kulit dan Kelamin Fakultas Kedokteran \\ Universitas Padjadjaran Rumah Sakit Dr. Hasan Sadikin Bandung
}

\begin{abstract}
Abstrak
Gonore adalah infeksi menular seksual (IMS) yang disebabkan oleh Neisseria gonorrhoeae ( $N$. gonorrhoeae). Salah satu manifestasi klinis gonore pada wanita adalah servisitis yang sebagian besar asimtomatik dan bila tidak diterapi servisitis gonore pada wanita hamil dapat menimbulkan komplikasi pada ibu, kehamilan, dan janin. Tujuan penelitian ini mengetahui prevalensi servisitis gonore pada wanita hamil di Rumah Sakit Khusus Ibu dan Anak (RSKIA) Kota Bandung tahun 2015. Penelitian ini merupakan penelitian deskriptif dengan desain potong lintang. Subjek penelitian adalah 100 wanita hamil dengan bahan pemeriksaan adalah apus endoserviks. Diagnosis servisitis gonore ditegakkan jika pada sedian apus gram ditemukan jumlah polimorfonuklear (PMN) >30/lapang pandang besar (lpb) dan diplokokus gram negatif intraseluler, serta hasil PCR N. gonorrhoeae positif. Hasil PCR $N$. gonorrhoeae pada seluruh subjek penelitian negatif. Namun, 41 orang (41\%) subjek penelitian ditemukan jumlah PMN >30/lpb, tanpa diplokokus gram negatif intraseluler, dan didiagnosis servisitis nongonore. Simpulan penelitian ini, yaitu prevalensi servisitis gonore pada wanita hamil di RSKIA Kota Bandung tahun 2015 adalah 0\%. Hasil tersebut diduga karena karakteristik sebagian besar subjek penelitian tidak termasuk ke dalam risiko tinggi mengidap IMS.
\end{abstract}

Kata kunci: Kehamilan, prevalensi, servisitis gonore

\section{Prevalence of Gonorrhea Cervicitis in Pregnant Women in Special Hospital Maternal and Child Bandung Year 2015}

\begin{abstract}
Gonnorhea is a sexually transmitted infection (STI) that is caused by Neisseria gonorrhoeae. One of the clinical manifestation of gonnorhea in female is cervicitis, that mostly asymptomatic. If it is left untreated, gonnorheal cervicitis in pregnant woman will cause complication to the mother, pregnancy, and fetus. The aim of this study was to know the prevalence of gonnorheal cervicitis in pregnant woman in mother and children hospital (RSKIA) Bandung in year 2015. The study design was cross sectional and descriptive. Subjects were 100 pregnant women, which was taken the sample from endocervical swab. Diagnosis of gonnorheal cervicitis was established if more than 30/high power field (hpf) polymorphonuclear (PMN) and extra or intracellular gram negative diplococcus found from gram staining, also positive PCR result for N. gonorrhoeae. The result of PCR in all subjects were negative. But, there were 41 subjects with PMN more than 30/hpf, with no intra or extra cellular diplococcus found, and those subjects were diagnosed as non gonnorheal cervicitis. Conclusion of this study was that the prevalence of gonorrheal cervicitis of pregnant woman in RSKIA Bandung in year 2015 is o\%. This result was suggested due to the subjects characteristics in this study mostly were not high risk for STI.
\end{abstract}

Key words: Gonorrheal cervicitis, pregnancy, prevalence

Korespondensi: arminaharamaini@gmail.com 


\section{Pendahuluan}

Gonore adalah merupakan salah satu penyakit dari infeksi menular seksual (IMS) paling banyak yang umum ditemukan di negara berkembang dan menjadi masalah kesehatan umum di dunia. ${ }^{1}$ Pada tahun 2008 World Health Organization (WHO) memperkirakan infeksi gonore sebanyak 106,1 juta orang dari total prevalensi IMS, yaitu 498,9 juta orang. ${ }^{2}$ Prevalensi gonore ditemukan tinggi pula pada kelompok sosial ekonomi dan tingkat pendidikan rendah, ${ }^{2}$ pendatang, laki suka laki (LSL), ${ }^{3}$ serta pada klien wanita pekerja seks (WPS). ${ }^{2}$ Faktor lain yang memengaruhi angka kejadian infeksi gonore tersebut antara lain adalah perilaku seksual, misalnya awitan dini aktivitas seksual, ${ }^{4}$ jumlah pasangan seksual multipel, status yang tidak menikah, riwayat infeksi gonore sebelumnya, dan riwayat IMS pada pasangan. ${ }^{3,4}$

Wanita dalam proses kehamilan merupakan suatu kelompok populasi risiko rendah dalam penularan IMS. ${ }^{5}$ Namun, Romoren dkk. ${ }^{5}$ telah melaporkan bahwa prevalensi servisitis gonore pada wanita hamil di Bostwana Nigeria cukup tinggi, yaitu sebesar $3 \%$. Diclemente dkk. ${ }^{6}$ juga melakukan penelitian terhadap 170 wanita hamil bangsa Afrika Amerika dan didapatkan hasil $1,2 \%$ wanita hamil terinfeksi gonore. Aboyeji dan Nwabuisi ${ }^{7}$ melakukan penelitian pada 230 wanita hamil asimtomatik yang melakukan ANC di Nigeria dan infeksi gonore ditemukan 1,3\%. Puspitasari $^{8}$ melakukan penelitian mengenai prevalensi servisitis gonore di Poliklinik Obstetri \& Ginekologi RSUP Dr. Hasan Sadikin Bandung mempergunakan pemeriksaan kultur dan hasil yang positif didapatkan pada dua orang (2\%).

Manifestasi infeksi gonore pada wanita hamil tidak jauh berbeda dengan wanita yang tidak hamil, ${ }^{3}$ akan tetapi sebagian besar infeksi pada endoserviks asimtomatik ${ }^{5}$ yang bila tidak terdeteksi dapat menimbulkan komplikasi pada ibu, kehamilan, dan juga janin. ${ }^{1}$ Dampak infeksi gonore yang mungkin terjadi pada kehamilan berupa korioamnionitis, abortus yang spontan, kehamilan prematur, 3,5 bayi berat badan lahir rendah (BBLR), ${ }^{5}$ ketuban pecah dini, dan infeksi gonokokus diseminata. ${ }^{3,5}$ Selain itu, infeksi gonore pada kehamilan dapat pula ditularkan pada bayi yang dilahirkan, seperti timbulnya keadaan oftalmia neonatorum gonore, ${ }^{3}$ uretritis, vaginitis, infeksi anorektal, faringitis, rinitis, funisitis, abses kulit kepala berambut, artritis, dan juga sepsis. ${ }^{4}$

Angka prevalensi servisitis gonore yang tinggi pada wanita yang hamil pada beberapa penelitian dan juga untuk mengurangi risiko komplikasi yang dapat terjadi maka sangat diperlukan penapisan rutin pada wanita yang hamil. ${ }^{5}$ Diagnosis gonore itu dapat ditegakkan berdasarkan atas identifikasi $N$. gonorrhoeae ${ }^{3}$ dengan beberapa metode, yaitu pemeriksaan mikroskopik, kultur, dan juga teknik molekuler. ${ }^{9}$ Pemeriksaan mikroskopik yang diambil dari duh tubuh endoserviks dengan cara pewarnaan gram merupakan cara pemeriksaan yang cepat, ${ }^{9}$ namun pada perempuan sensitivitasnya rendah, kurang dari $55 \% .{ }^{9}$ Teknik molekuler polymerase chain reaction (PCR) mempunyai sensitivitas lebih tinggi bila dibanding dengan kultur,, yaitu $90-100 \%,{ }^{9}$ sedangkan pemeriksaan kultur sebesar 68,2\%. ${ }^{9}$ Metode ini dapat menggantikan kultur terutama pada pasien asimtomatik..$^{10}$

Rumah Sakit Khusus Ibu dan Anak (RSKIA) Kota Bandung merupakan satu-satunya Rumah Sakit Khusus Ibu dan Anak di Kota Bandung milik Pemerintah Kota Bandung. ${ }^{11}$ Data kunjungan antenatal care (ANC) yang didapatkan dari statistik di RSKIA Kota Bandung menunjukkan bahwa kunjungan ANC adalah sebanyak 60-70 orang wanita hamil per hari.

Sampai sekarang ini, penelitian mengenai angka kejadian servisitis gonore pada wanita hamil di RSKIA Kota Bandung belum pernah dilaksanakan sebelumnya. Berdasarkan atas hal itu, penulis bermaksud melakukan penelitian tersebut dengan pertimbangan bahwa RSKIA itu menjadi pusat pelayanan ANC wanita hamil di Kota Bandung dengan jumlah kunjungan yang cukup besar. Penelitian ini mempunyai tujuan mengetahui prevalensi servisitis gonore pada wanita hamil dengan lokasi yang dipilih, yaitu di RSKIA Kota Bandung.

\section{Metode}

Penelitian ini merupakan penelitian deskriptif observasional memakai metode potong lintang. Peserta pada penelitian ini adalah seluruh wanita hamil yang berobat untuk ante natal care (ANC) ke Poliklinik Kebidanan dan Kandungan RSKIA Kota Bandung tanpa melihat lagi usia kehamilan baik pada trimester pertama, kedua, atau ketiga, kecuali wanita hamil dengan risiko yang tinggi abortus, perdarahan, atau kontraksi prematur dari anamnesis riwayat kehamilan saat ini. Hal 
Tabel 1 Karakteristik Subjek Penelitian

\begin{tabular}{|c|c|}
\hline Variabel & $\mathbf{n}=\mathbf{1 0 0}$ \\
\hline \multicolumn{2}{|l|}{ Usia (tahun) } \\
\hline$<25$ & 29 \\
\hline $25-35$ & 54 \\
\hline$>35$ & 17 \\
\hline \multicolumn{2}{|l|}{ Pendidikan } \\
\hline Tidak sekolah & o \\
\hline Tamat SD & 12 \\
\hline Tamat SLTP & 23 \\
\hline Tamat SLTA & 54 \\
\hline Perguruan tinggi & 11 \\
\hline \multicolumn{2}{|l|}{ Pekerjaan } \\
\hline Wiraswasta & 5 \\
\hline Karyawan swasta & 14 \\
\hline PNS & 1 \\
\hline Tidak bekerja & 79 \\
\hline PNS+wiraswasta & 1 \\
\hline \multicolumn{2}{|l|}{ Status pernikahan } \\
\hline Belum menikah & o \\
\hline Menikah & 100 \\
\hline \multicolumn{2}{|l|}{ Usia kehamilan } \\
\hline Trimester 1 & 7 \\
\hline Trimester 2 & 12 \\
\hline Trimester 3 & 81 \\
\hline \multicolumn{2}{|l|}{ Jumlah ANC } \\
\hline 1 kali & 3 \\
\hline$>1$ kali & 97 \\
\hline \multicolumn{2}{|c|}{ Riwayat kehamilan sebelumnya } \\
\hline Abortus & 22 \\
\hline Kelahiran prematur & 6 \\
\hline BBLR & 5 \\
\hline Hamil ektopik & 1 \\
\hline Bayi lahir meninggal & 4 \\
\hline Tanpa riwayat kelainan & 62 \\
\hline \multicolumn{2}{|l|}{ Keluhan saat ini } \\
\hline Tanpa keluhan & 21 \\
\hline Keputihan & 74 \\
\hline Disuria & 3 \\
\hline Perdarahan pascakoitus & 2 \\
\hline Lain-lain & $\mathrm{O}$ \\
\hline \multicolumn{2}{|l|}{ Domisili suami } \\
\hline Sering ke luar kota & 27 \\
\hline Tidak & 73 \\
\hline
\end{tabular}

ini berdasarkan atas seleksi yang dilakukan oleh dokter spesialis kebidanan dan kandungan.

Sebanyak 100 orang peserta penelitian yang memenuhi kriteria dan dipilih secara consecutive sampling dilakukan anamnesis, pemeriksaan luar dan pemeriksaan venereologik, kemudian dilakukan dua kali pengambilan sampel apus endoserviks memakai endocervical collection swab untuk dilakukan pemeriksaan PCR bakteri $N$. gonorrhoeae dan pemeriksaan mikroskopik dengan pewarnaan gram.

\section{Hasil}

Berdasarkan atas Tabel 1 subjek penelitian ini terbanyak berusia 25-35 tahun, pendidikan tamat SLTA, dan tidak bekerja atau sebagai ibu rumah tangga. Status pernikahan pada semua subjek penelitian, yaitu status menikah dan usia kehamilan subjek penelitian terbanyak adalah trimester ke-3. Sebagian besar subjek penelitian ini melakukan ANC $>1$ kali selama kehamilan. Keluhan paling banyak pada waktu dilaksanakan wawancara adalah keputihan. Sebagian kecil suami dari subjek penelitian sering ke luar kota sehubungan dengan pekerjaannya.

Berdasarkan atas Tabel 2 sebagian besar subjek penelitian mendapat coitarche $\geq 20$ tahun dan melakukan hubungan seksualnya pertama kali dengan suami. Seluruh subjek penelitian mengaku pasangan seksual saat ini hanya dengan suami. Jumlah pasangan seksual 1 (satu) orang didapatkan pada 88 orang subjek penelitian ini dan pada 12 orang subjek penelitian memiliki jumlah total pasangan seksual $>1$ orang karena menikah 2 (dua) kali. Riwayat menggunakan narkoba jenis suntik hanya diakui oleh seorang subjek penelitian ini. Seluruh subjek penelitian mengaku tidak pernah mempunyai riwayat IMS.

Pada Tabel 3 diperlihatkan seluruh subjek penelitian ini tidak mempunyai kelainan kulit dan pembesaran kelenjar getah bening (KGB). Kelainan pada ektoserviks subjek penelitian terdiri atas eritema (45\%), ektopi (19\%), dan serviks yang rapuh atau mudah berdarah (15\%).

Berdasar atas Tabel 4 didapatkan bahwa duh tubuh pada orifisium uteri eksterna ditemukan pada sebagian besar subjek penelitian ini dengan karakteristik duh terbanyak berupa konsistensi mukoid, jumlah sedikit, dan berwarna bening.

Pada Tabel 5 dapat dilihat berdasar atas pemeriksaan mikroskopis pada 41 orang subjek penelitian memiliki jumlah PMN >30/lpb dan 
Tabel 2 Karakteristik Perilaku Seksual Subjek Penelitian

\begin{tabular}{|c|c|}
\hline Variabel & $\mathbf{n}=\mathbf{1 0 0}$ \\
\hline \multicolumn{2}{|l|}{ Usia coitarche (tahun) } \\
\hline$<20$ & 30 \\
\hline$\geq 20$ & 70 \\
\hline \multicolumn{2}{|l|}{ Pasangan seks saat ini } \\
\hline Hanya suami & 100 \\
\hline Pasangan tetap & o \\
\hline Pasangan tidak tetap & o \\
\hline \multicolumn{2}{|l|}{ Jumlah pasangan seksual } \\
\hline 1 orang & 88 \\
\hline$>1$ orang & 12 \\
\hline \multicolumn{2}{|l|}{ Orientasi seksual } \\
\hline Heteroseksual & 100 \\
\hline Biseksual & o \\
\hline \multicolumn{2}{|l|}{ Cara berhubungan seksual } \\
\hline KK (kelamin kelamin) & 57 \\
\hline KK+MK (mulut kelamin) & 41 \\
\hline KK+AK (anal kelamin) & 1 \\
\hline $\mathrm{KK}+\mathrm{MK}+\mathrm{AK}$ & 1 \\
\hline \multicolumn{2}{|l|}{$\begin{array}{l}\text { Riwayat penggunaan narkoba } \\
\text { suntik }\end{array}$} \\
\hline Tidak & 99 \\
\hline $\mathrm{Ya}$ & 1 \\
\hline \multicolumn{2}{|l|}{ Riwayat IMS sebelumnya } \\
\hline Tidak ada & 100 \\
\hline Duh tubuh, borok, vesikel, kutil & o \\
\hline
\end{tabular}

seluruhnya didapatkan dari subjek penelitian dengan duh tubuh serviks positif. Namun, dari 41 orang tersebut tidak seorangpun ditemukan diplokokus gram negatif intraseluler maupun ekstraseluler.

Tabel 6 di atas memperlihatkan bahwa hasil PCR N. gonorrhoeae adalah o\%. Berdasarkan atas hasil pemeriksaan gram dan juga ditunjang dengan hasil PCR yang memperlihatkan hasil negatif maka disimpulkan prevalensi servisitis gonore pada wanita hamil dalam penelitian ini adalah $0 \%$. Pada sebanyak 41 orang subjek penelitian yang memiliki jumlah PMN >30/ lpb tidak ditemukan bakteri diplokokus gram negatif baik intraseluler ataupun ekstraseluler dan hasil PCR negatif didiagnosis sebagai servisitis nongonore.

\section{Pembahasan}

Prevalensi servisitis gonore pada wanita yang hamil menurut berbagai penelitian bervariasi, berkisar $0-10 \%{ }^{12,13}$ Prevalensi servisitis gonore pada wanita hamil dalam penelitian ini adalah o\%. Hasil prevalensi o\% ini serupa dengan penelitian yang dilakukan Moaiedmohseni dkk. ${ }_{12}$ di Iran.Penelitian tersebut dilaksanaan di klinik ANC dan didapatkan bahwa karakteristik sebagian besar subjek penelitian memiliki faktor risiko rendah mengidap gonore, yaitu sebagian besar berstatus telah menikah dengan tingkat pendidikan paling banyak minimal SMA dan hanya memiliki satu pasangan seksual. Pada penelitian Moaiedmohseni dkk. ${ }^{12}$ disimpulkan bahwa keyakinan agama dan gaya hidup subjek penelitian diduga dapat melindungi masyarakat dari perilaku seksual yang berisiko. Karakteristik subjek pada penelitian ini serupa dengan yang dilaporkan oleh Moaiedmohseni dkk.

Status yang tidak menikah disimpulkan menjadi salah satu faktor risiko dapat mengidap gonore. ${ }^{14}$ Keadaan ini disebabkan karenaindividu yang belum menikah memiliki kecenderungan melakukan hubungan seksual secara bebas sehingga risiko tertular IMS meningkat. ${ }^{14}$

Tingkat pendidikan yang rendah sering kali dihubungkan juga dengan peningkatan frekuensi dan juga risiko mengidap IMS. Solomon dkk. ${ }^{15}$ menyimpulkan juga dalam penelitiannya bahwa individu yang tidak menyelesaikan sekolah dasar (SD) ataupun pendidikan terakhir SD memiliki frekuensi mengidap IMS ataupun risiko IMS yang lebih tinggi. Nyarko dkk. ${ }^{16}$ menyimpulkan bahwa salah satu faktor risiko tinggi untuk IMS adalah tingkat pendidikan yang rendah. Pendidikan rendah itu berpengaruh terhadap berperilaku seksual yang tidak aman sehingga dapat meningkatkan risiko IMS. ${ }^{16,17}$

Jumlah pasangan seksual yang multipel merupakan faktor risiko untuk dapat mengidap gonore. Risiko mengidap gonore tersebut akan meningkat bila selama hamil mempunyai $>1$ pasangan seksualnya. ${ }^{18}$ Hubungan seksual yang hanya dilakukan dengan pasangan yang telah dinikahi dapat membatasi individu dari perilaku seksual tidak aman sehingga dapat mencegah tertular IMS. ${ }^{17}$

Penelitian prevalensi gonore pada wanita yang hamil dengan hasil rendah, yaitu $0,2-1,18 \%$ dilaporkan oleh Hassanzadeh dkk., ${ }^{19}$ Moleka dkk., ${ }^{20}$ juga oleh Bakhtiari dan Firoozjahi, ${ }^{21}$ serta 
Tabel 3 Karakteristik Pemeriksaan Fisik, Status Venereologikus, dan Pemeriksaan Inspekulo Subjek Penelitian

\begin{tabular}{lcc}
\hline \multicolumn{1}{c}{ Variabel } & Tidak & Ya \\
\hline Pemeriksaan venereologikus & 100 & O \\
Pembesaran KGB inguinal & 100 & O \\
Lesi di pubis & 100 & 0 \\
Rambut pubis (kutu/telur kutu) & 97 & 3 \\
Lesi di labia mayor & 99 & 1 \\
Lesi di labia minora & 100 & 0 \\
Pembesaran kelenjar Bartolin & 100 & 0 \\
Pembesaran kelenjar Skene & 100 & 0 \\
Lesi di meatus uretra eksternus & 100 & 0 \\
Duh tubuh di meatus uretra eksternus & 69 & 31 \\
Duh tubuh di introitus vagina & 99 & 1 \\
Lesi perianal & & 19 \\
Inspekulo ektoserviks & & 15 \\
Eritema & 55 & 93 \\
Ektopi & 81 & 45 \\
Mudah berdarah & 85 & 7 \\
Duh tubuh di orifisium uteri eksterna & & \\
\hline
\end{tabular}

Tabel 4 Karakteristik Keluhan Keputihan dan Duh Tubuh Serviks

\begin{tabular}{|c|c|}
\hline Variabel & Jumlah $(n=100)$ \\
\hline \multicolumn{2}{|l|}{ Duh tubuh serviks } \\
\hline Tidak ditemukan & 7 \\
\hline Ditemukan & 93 \\
\hline \multicolumn{2}{|l|}{ Konsistensi } \\
\hline Serosa & 10 \\
\hline Mukoid & 81 \\
\hline Menggumpal & 2 \\
\hline \multicolumn{2}{|l|}{ Jumlah } \\
\hline Sedikit & 48 \\
\hline Sedang & 38 \\
\hline Banyak & 7 \\
\hline \multicolumn{2}{|l|}{ Warna } \\
\hline Bening & 37 \\
\hline Putih & 31 \\
\hline $\begin{array}{l}\text { Putih kekuningan } \\
\text { (mukopurulen) }\end{array}$ & 24 \\
\hline Kehijauan & 1 \\
\hline
\end{tabular}

Thamlasangy dkk.22

Penelitian oleh Hassanzadeh dkk.19 terhadap 1.100 wanita hamil dengan pemeriksaan PCR dan didapatkan hasil bahwa prevalensi gonore sebesar $1,18 \%$ atau 13 orang. Prevalensi yang rendah tersebut disebabkan oleh karena faktorfaktor risiko untuk mengidap gonore seperti status ekonomi yang rendah, riwayat IMS yang

Tabel 5 Hasil Pemeriksaan Mikroskopis dari Duh Tubuh Serviks dengan Pewarnaan Gram

\begin{tabular}{lc}
\hline Variabel & Jumlah (n=10o) \\
\hline Duh tubuh serviks (+) & \\
PMN 1-10/lpb & 13 \\
PMN 11-20/lpb & 13 \\
PMN 21-30/lpb & 26 \\
PMN >30/lpb & 41 \\
Duh tubuh serviks (-) & \\
PMN 1-10/lpb & 1 \\
PMN 11-20/lpb & 3 \\
PMN 21-30/lpb & 3 \\
PMN >30/lpb & 0 \\
\hline
\end{tabular}


Tabel 6 Hasil Pemeriksaan PCR N. gonorrhoeae

\begin{tabular}{lc}
\hline $\begin{array}{c}\text { Hasil PCR } \\
\text { N.gonorrhoeae }\end{array}$ & Jumlah $(\mathbf{n}=\mathbf{1 0 0})$ \\
\hline Positif & 0 \\
Negatif & 100 \\
\hline
\end{tabular}

sebelumnya, pengangguran, pendidikan yang rendah, penggunaan minuman beralkohol dan narkoba, serta mempunyai pasangan seksual yang multipel pada subjek dan pasangan seksual tidak didapatkan pada sebagian besar subjek penelitian. Faktor-faktor lainnya adalah agama, tata krama, stigma sosial, dan rasa malu di masyarakat Iran mengenai hubungan seksual bebas dapat mengurangi individu dari perilaku seksual berisiko.

Karakteristik subjek penelitian ini serupa dengan yang dilaporkan oleh Hassanzadeh dkk. ${ }^{19}$ Selain itu, faktor agama, sosial, dan tata krama di Indonesia yang masih menentang hubungan seksual yang di luar pernikahan berpengaruh pula dalam hal mencegah perilaku hubungan seksual bebas sehingga dapat mengurangi risiko tertular IMS.

Riwayat tentang penggunaan narkoba dan juga pernah mengidap IMS sebelumnya pada wanita hamil mempunyai nilai prediktif positif mengidap gonore sebesar $6,1 \% .^{23}$ Penggunaan narkoba berhubungan juga dengan peningkatan berperilaku seksual berisiko yang tidak aman sehingga rentan untuk mengidap IMS. ${ }^{24}$

Pada penelitian oleh Thamlasangy dkk. ${ }^{22}$ dilaporkan bahwa prevalensi servisitis gonore yang rendah pada wanita hamil sebesar $0,8 \%$. Karakteristik sebagian besar subjek penelitian ini adalah sebagai ibu rumah tangga dan memiliki status ekonomi yang cukup baik. Karakteristik subjek penelitian pada penelitian ini serupa dengan yang dilaporkan oleh Thamlasangy dkk. Usanga dkk. ${ }^{25}$ menyimpulkan bahwa prevalensi IMS terendah didapatkan pada ibu rumah tangga. Hal ini diduga disebabkan oleh ibu yang tidak bekerja memiliki situasi kehidupan rumah tangga cenderung lebih stabil sehingga hal ini berperan dalam mencegah berperilaku seksual berisiko tinggi. ${ }^{25}$

Moleka dkk. ${ }^{20}$ juga telah melaporkan bahwa prevalensi servisitis gonore yang diderita oleh wanita hamil yang berkunjung ke klinik ANC sebesar $0,4 \%$. Prevalensi yang rendah tersebut disebabkan oleh karena subjek penelitian hanya diambil dari dua klinik ANC sehingga tidak merepresentasikan populasi wanita hamil yang sebenarnya.

Bakhtiari dan Firoozjahi ${ }^{21}$ juga melakukan penelitian mengenai prevalensi dan faktor risiko servisitis gonore pada wanita usia reproduktif yang datang berobat ke klinik ginekologi dan didapatkan angka prevalensinya sebesar $0,2 \%$. Prevalensi yang rendah dapat disebabkan oleh pemilihan subjek penelitian yang dilakukan secara acak, tanpa memperhatikan ada tidaknya gejala dan tanda klinis gonore.

Pada penelitian ini subjek penelitian dipilih secara acak berdasarkan atas urutan kedatangan tanpa memperhatikan ada atau tidaknya gejala dan tanda klinis gonore serta diambil hanya dari satu tempat penelitian, serupa dengan alasan rendahnya prevalensi gonore yang dilaporkan Moleka dkk. ${ }^{20}$ serta Bakhtiari dan Firoozjahi. ${ }^{21}$

Beberapa penelitian telah melaporkan bahwa prevalensi servisitis gonore tinggi pada wanita hamil seperti yang dilaporkan oleh Wangnapi dkk. ${ }^{26}$ serta Bergren dan juga oleh Patchen. ${ }^{24}$ Wangnapi dkk. ${ }^{26}$ melaporkan bahwa prevalensi servisitis gonore juga tinggi pada wanita hamil sebesar 9,7\%. Sebagian besar subjek penelitian ini coitarche pada usia 17-20 tahun. Riwayat mempunyai pasangan seksual selain suaminya didapatkan pada 20,9\% subjek penelitian dan riwayat suami memiliki pasangan seksual lain didapatkan pada sebanyak 22,7\%. Karakteristik subjek pada penelitian ini berbeda dengan karakteristik subjek penelitian yang dilaporkan Wangnapi dkk. ${ }^{26}$

Coitarche pada usia $\leq 16$ tahun merupakan salah satu faktor risiko mengidap gonore yang bermakna. ${ }^{13}$ Usia muda pada saat pertamakalinya berhubungan seksual dapat dihubungkan juga dengan banyaknya pasangan seksual sehingga meningkatkan risiko penularan IMS. ${ }^{27}$ Bergren dan Patchen ${ }^{24}$ melaporkan prevalensi servisitis gonore pada wanita hamil yang mempunyai faktor risiko IMS berdasarkan atas usia adalah berusia $12-18$ tahun sebesar $10 \%$ (13 orang dari total subjek penelitian 125 orang). Aboyeji dan Nwabuisi ${ }^{7}$ melakukan penelitian pada 230 wanita hamil yang asimtomatik dan didapatkan prevalensi servisitis gonore sebanyak $1,3 \%$ atau 3 orang. Semua pasien dengan servisitis gonore tersebut didapatkan pada kelompok usia 19-24 tahun.

Pada penelitian ini sebagian besar subjek berusia 25-35 tahun. Karakteristik subjek pada penelitian ini berbeda dengan yang dilaporkan 
oleh Bergren dan Patchen ${ }^{24}$ serta Aboyeji dan Nwabuisi ${ }^{7}$ sehingga dapat disimpulkan bahwa sebagian besar peserta penelitian ini bukanlah kelompok risiko tinggi gonore berdasarkan usia.

Usia sangat memengaruhi hal pengetahuan dan juga pemahaman individu mengenai IMS. Remaja atau usia muda umumnya memiliki pengetahuan yang rendah mengenai IMS ${ }^{15}$ serta memiliki aktivitas seksual yang lebih tinggi ${ }^{7,15}$ sehingga pada kelompok ini lebih rentan untuk terkena IMS..$^{715}$ Blatt dkk. ${ }^{28}$ melakukan analisis regresi multivariat terhadap usia wanita hamil asimtomatik yang terinfeksi $N$. gonorrhoe dan didapatkan hasil bahwa risiko mengidap gonore pada wanita hamil usia $35-40$ tahun, ternyata 8 kali lebih rendah dibanding dengan usia 16-24 tahun.

Faktor lainnya yang sebagai faktor risiko untuk mengidap gonore, yaitu jumlah kunjungan ANC. Sebagian besar subjek penelitian (97\%) melakukan ANC >1 kali. Ibu hamil yang tidak atau yang jarang melakukan pemeriksaan ANC berisiko menderita gonore oleh karena pada saat ANC dapat dilakukan pemeriksaan penapisan dan sekaligus pemberian terapi yang tepat bila positif terinfeksi. ${ }^{26}$

Keluhan paling banyak pada saat dilakukan wawancara adalah "keputihan", paling banyak dengan konsistensi kental, jumlahnya sedikit, dan berwarna putih. Servisitis gonore bersifat asimtomatik terdapat pada 50-80\% pasien, ${ }^{29}$ bila bergejala dapat berupa keputihan dengan duh tubuh purulen atau mukopurulen. ${ }^{3}$ Pada penelitian ini sebanyak 24 subjek penelitian ditemukan duh tubuh serviks yang mukopurulen, pada 18 di antaranya ditemukan $\mathrm{PMN}>30 / \mathrm{lpb}$, namun tidak seorangpun ditemukan diplokokus gram negatif ataupun hasil PCR N. gonorrhoeae yang positif.

Kelainan yang didapatkan pada ektoserviks subjek penelitian ini terdiri atas eritema (45\%), ektopi (19\%), dan juga serviks yang rapuh dan mudah berdarah (15\%). Jackson dkk. ${ }^{30}$ telah menyimpulkan bahwa indikator klinis servisitis pada wanita yang sedang hamil tidak mempunyai nilai kepercayaan yang tinggi. Selama proses kehamilan dapat terjadi perubahan karakteristik yang normal pada serviks, antara lain sianosis, perlunakan serviks, peningkatan vaskularisasi, edema, eritema, serta hiperplasia dan hipertrofi kelenjar endoserviks sehingga menjadi ektopi. ${ }^{31}$

Servisitis nongonore pada penelitian ini didapatkan sebanyak 41 orang subjek penelitian.
Beberapa patogen sudah dianggap penyebab dari servisitis nongonore itu adalah antara lain Chlamydia trachomatis, juga Herpes simplex virus, Trichomonas vaginalis, ${ }^{32}$ atau organismeorganisme yang berhubungan dengan vaginosis yang disebabkan oleh bakteri, yaitu termasuk Mycoplasma genitalium (M. genitalium), ${ }^{32,33}$ M. hominis, Bacteriodes spp., juga Gardnerella vaginalis. ${ }^{33}$ Enterococcus spp., Bacteriodes fragilis, dan Escherichia coli telah dilaporkan pula dapat sebagai penyebabnya servisitis yang bukan ditularkan melalui hubungan seksual. ${ }^{34}$

Penyebab negatif palsu pada pemeriksaan PCR antara lain oleh karena kesalahan operator dan juga kegagalan reagen atau peralatan, serta kompetitif amplifikasi dan variasi untai DNA di antara subtipe $N$. gonorrhoeae. $^{10}$

Kompetitif amplifikasi dapat terjadi pada PCR multipleks yang mendeteksi dua organisme yang terjadi bersamaan. ${ }^{10} \mathrm{Hal}$ ini terjadi apabila konsentrasi asam nukleat salah satu organisme target jauh lebih tinggi bila dibanding dengan organisme target yang lain sehingga organisme dengan konsentrasi yang lebih rendah gagal teramplifikasi. ${ }^{10}$ Pada penelitian ini digunakan PCR multipleks.

Variasi untai DNA pada N. gonorrhoeae berbeda berdasarkan geografis dan juga berbeda terhadap tiap-tiap kelompok pasien. ${ }^{10}$ Dyck dkk. ${ }^{35}$ melaporkan terdapatnya bahan pemeriksaan dengan hasil negatif pada pemeriksaan PCR untuk N. gonorrhoeae, akan tetapi memberikan hasil yang positif pada pemeriksaan kultur. Keadaan ini diduga akibat variasi untai DNA $N$. gonorrhoeae.

Pada penelitian ini kit BiONEER yang dipergunakan mempunyai target pada gen porA. Namun, tidak dapat dipastikan apakah terdapat variasi gen por A N. gonorrhoeae oleh karena memerlukan pemeriksaan lebih lanjut.

\section{Simpulan}

Pada penelitian ini prevalensi servisitis gonore pada wanita hamil di RSKIA Kota Bandung pada tahun 2015 adalah 0\%. Sebagian besar subjek pada penelitian ini berusia 25-35 tahun, berpendidikan SLTA, tidak bekerja, coitarche $\geq 20$ tahun, dan tidak memakai narkoba suntik. Seluruh subjek penelitian ini berstatus menikah, memiliki pasangan seksual hanya suami, dan tidak memiliki riwayat IMS sebelumnya.

Pada penelitian ini kurang dari setengah 
subjek penelitian jumlah PMN >30/lpb tanpa ditemukan bakteri diplokokus gram negatif intra ataupun ekstraseluler dan PCR N. gonorrhoeae negatif sehingga didiagnosis sebagai servisitis nongonore.

\section{Ucapan Terima Kasih}

Ucapan terima kasih kepada semua pihak, yaitu Dekan Fakultas Kedokteran Universitas Padjadjaran, kepada Kepala Departemen Ilmu Kesehatan Kulit dan Kelamin FK Unpad/ RSHS Dr. dr. Oki Suwarsa, M.Kes., SpKK(K), Direktur RSKIA Kota Bandung, Kepala dan staf Departemen Obstetri Ginekologi RSKIA Kota Bandung, dan Laboratorium RS Rajawali Bandung.

\section{Daftar Pustaka}

1. Bala M, Mullick JB, Muralidhar S, Kumar J, Ramesh V. Gonorrhoea prevalence \& co-infection with other ulcerative, nonulcerative sexually transmitted \& HIV infection in a regional STD Centre. Indian J Med Res. 2011;133:346-9.

2. Global prevalence and incidence of selected curable sexually transmitted infections. WHO. Geneva: Departement of Communicable Diseases Surveillance and Response; 2008.

3. Hook EW, Handsfield HH. Gonococcal infections in adults. Dalam: Holmes KK, Sparling PF, Stamm WE, Piot P, Wasserheit JN, Corey L, penyunting. Sexually transmitted disease. Edisi ke-4. New York: McGraw-Hill; 2008. hlm. 627-45.

4. Walker CK, Sweet RL. Gonorrhea infection in women: prevalence, effects, screening, and management. Int J W Health. 2011;3:197206.

5. Romoren M, Sundby J, Velauthapillai M, Rahman M. Chlamydia and gonorrhea in pregnant Bastwana women: time to discard the syndromic approach?. BMC Infec Dis. 2007;7:27.

6. Diclemente RJ, Wingood GM, Crosby RA, Rose E. A descriptive analysis of STD prevalence among urbant pregnant AfricanAmerican teens: data from a pilot study. J Adolescent Health. 2004;34:376-83.

7. Aboyeji AP, Nwabuisi C. Prevalence of sexually transmitted disease among pregnant women in Illorin, Nigeria. J Obstet Gynecol. 2003;23:637-9.

8. Puspitasari D. Prevalensi servisitis gonore pada ibu hamil di Poliklinik Kebidanan RSP Dr. Hasan sadikin Bandung berdasarkan pemeriksaan kultur [tesis]. Bandung: Fakultas Kedokteran Universitas Padjadjaran; 1998.

9. Bignell C. 2009 European (IUSTI/WHO) guideline on the diagnosis and treatment og gonorrhea in adults. Int J STD AIDS. 2009:453-7.

10. Whiley DM, Tapsall JW, Sloots TP. Nucleic acid amplification testing for Neisseria gonorrhoeae: an ongoing challenge. $\mathrm{J}$ Mol Diagn. 2006;8(1):3-15.

11. Pusat Data dan Informasi PERSI. Rumah Sakit Astana Anyar [diunduh 6 September 2014]. Tersedia dari: http://www.pdpersi. co.id/content/hcpage.php? $=219$

12. Moaiedmohseni S, Bashardoost L, Abbasi M. Cervicovaginal infections during third trimester of pregnancy. J Fam Repr Health. 2012;6(1):11-5.

13. Shin J, Donegan SP, Heeren TC, Greenberg M. Transmission of Chlamydia trachomatis and Neisseria gonorrhoeae among men with urethritis and their female sex partners. $\mathrm{J}$ Infect Dis. 1998;178:1707-12.

14. Edem A, Ntekpe M, Umoekam N. Prevalence of syphilis and gonorrhea in patient attending General Hospital, Calabar, Nigeria. Int J Modern Biol Med. 2013;4(3):155-68.

15. Solomon MM, Smith MJ, Rio CD. Low educational level: a risk factor for sexually transmitted infections among commercial sex workers in Quito, Ecuador. Int J STD AIDS. 2008;19:264-7.

16. Nyarko C, Unson C, Koduah M. Risk factors of sexually transmitted infections (stis) among men and women in a mining community in western Ghana: a study of lifetime occurrence. Int $\mathrm{J}$ Scie Technol. 2014;3(12):361-9.

17. Situmorang A. Adolescent Reproductive Health in Indonesia. 2003:1-20.

18. Braddick MR, Achola JO, Mirza NB. Towards developing a diagnostic algorithm for Chlamydia trachomatis and Neisseria gonorrhoeae cervicitis in pregnancy. Genito Urin Med. 1990;66:62-5.

19. Hassanzadeh P, Mardaneh J, Motamedifar M. Coventional agar based culture method, 
and nucleic acid amplification test (NAAT) of the cppB gene for detection of Neisseria gonorrhoeae in pregnant women endocervical swab specimens. Ir R Cresc Med J. 2013;15(3):207-11.

20. Moleka RK, Smith JS, Atibu J. Low prevalence of HIV and other selected sexually transmitted infections in 2004 in pregnant women from Kinshasa, the Democratic of the Congo. Epidemiol Infect. 2008;136:1290-6.

21. Bakhtiari A, Firoozjahi AR. The prevalence of gonococcal infection in non pregnant women. Iranian J Pub Health. 2007;36(2):64-7.

22. Thammlangsy S, Sihavong A, Pbouthavane $\mathrm{T}$, Suyubonthavony K. The prevalence of lower genital tract infections among antenatal care (ANC) clinics patient in two centrals hospitals, Viantiene, Lao People 's Democratic Republic. J Trop Med Public Health. 2006;37(1):190-9.

23. Magriples U, Copel JA. Can risk factor assessment replace universal screening for gonorrhea and chlamydia in the third trimester?. Am J Perinatol. 2001;18(8):658.

24. Berggren EK, Patchen L. Prevalence of Chlamydia trachomatis and Neisseria gonorrhoeae and repeat infection among pregnant urban adolescents. Sex Transm Dis. 2011;38(3):172-4.

25. Usanga V, Bassey LA, Etoh PI, Udoh S, Ani F, Archibong E. Prevalence of sexually transmitted disease in pregnant and non pregnant women in Calabar, cross River State, Nigeria. Intern J Gynecol. 2009;14(2).

26. Wangnapi RA, Soso S, Unger HW, Sawera C. Prevalence and risk factors for Chlamydia trachomatis, Neisseria gonorrhoeae and Trichomonasvaginalis infection in pregnant women in Papua New Guinea. Sex Transm Infect. 2015 May;91(3):194-200.

27. Venkatesh KK, Straten A, Mayer KH, Blanchard K. African women recently infected with HIV1 and HSV2 have increased risk of acquiring Chlamydia trachomatis and Neisseria gonorrhoeae in the methods for improving reproductive health in Africa Trial Sex Transm Infect. 2011;38(6):56270.

28. Blatt AJ, Lieberman JM, Hoover DR, Kaufman HW. Chlamydial and gonococcal testing during pregnancy in the United States. Am J Obstet Gynecol. 2012;207:55. e1-8.

29. Stary A. Sexually transmitted infections. Dalam: Bolognia JL, Jorizzo JL, Rapini RP, penyunting. Dermatology. Edisi ke-2. Edinburgh: Mosby Elsevier; 2008. hlm. 1239-61.

30. Jackson SL, O'Connell NG, Borzelleca JF. Cervicitis as a clinical indicator of gonococcal and Chlamydia infections in pregnancy. Infect Dis Obs Gyn. 1995;3:184-8.

31. Repke JT, Berlin L, Spence M, Horn J, MacKenzie E. Reproducibility of diagnosis of cervicitis in pregnancy. Am J Perinatol. 1988;5(3):242-6.

32. Holmes KK, Stamm WE, Sobel JD. Lower genital tract infection syndromes in women. Dalam: Holmes KK, Sparling PF, Stamm WE, Piot P, Wasserheit JN, Corey L, dkk., penyunting. Sexually transmitted diseases. Edisi ke-4. New York: McGraw-Hill; 2008. hlm. 987-1010.

33. Hillier SL, Khron MA, Nugent RP, Gibbs RS. Characteristics of three vaginal flora patterns assessed by Gram stain among pregnant woman. Am J Obstet Gynecol. 1992;166(3):938-44.

34. Lurie S, Asaala H, Harari OS, Golan A, Sadan O. Uterine cervical non-gonococcal and non-chlamydial bacterial flora and its antibiotic sensitivity in woman with pelvic inflammatory disease: did it vary over 20 years?. Isr Med Assoc J. 2010;12:747-9.

35. Dyck VE, Ieven M, Pattyn S, Van DL, Laga M. Detection of Chlamydia trachomatis dan Neisseria gonorrhoeae by enzyme immunoassay, culture, and three nucleic acid amplification test. J Clin Microbiol. 2001;39:1751-6. 